\title{
PENGUATAN INDUSTRI KENDARAAN BERMOTOR
}

\section{STRENGTHENING OF VEHICLE INDUSTRY}

\author{
Irwan Ibrahim \\ Pusat Teknologi dan Industri Sistem Transportasi, \\ Deputi Teknologi Industri Rancang Bangun dan Rekayasa, BPPT \\ Gedung Teknologi 2, Kawasan Puspiptek, Serpong \\ Tlp. 75875941-758759 Ext 147 \\ email:wanibra@yahoo.com
}

\begin{abstract}
Abstrak
Produksi industri mobil terus mobil meningkat dalam beberapa tahun ini. Pada tahun 2012 mencapai 1,065 juta unit. Peraturan Presiden No. 28/2008 menetapkan sasaran produksi tahun 2015 sebanyak 1,6 juta unit yang terdiri dari mobil jenis MPV, truk ringan, kendaraan bermotor hemat energi dan bersahabat dengan lingkungan. Sasaran ekspor juga ditetapkan 386 ribu unit. Namun peran potensi lokal dalam bidang teknologi masih sangat terbatas. Upaya harus dikembangkan untuk memperkutan struktur industri mobil dengan melibatkan kapasitas dalam negeri. Tulisan ini mencoba mengemukakan sebuah alternatif pendekatan dan strategi untuk membuat industri mobil menjadi lebih kuat.
\end{abstract}

Kata kunci: Mobil, Industri, Kapasitas Dalam Negeri

\begin{abstract}
The production volume of automobile industries increases over the years. In 2012 it reached 1.065 million units. The Presidential Regulation No. 28/2008 stipulates the production target of 1.6 million units in 2015 of MPV's type, light trucks and energy saving \& environmentally friendly vehicles. The export target in 2015 is set for 386,000 units. However, the role of local potential in technology is very limited. Effort has to be assessed to strengthening the structure of automobile industry taking into account local capacities. This paper tries to present an alternative approach and strategy to make the automobile industry stronger.
\end{abstract}

Key words: Car, Local Capacity, Industry

Diterima (received) : 5 Mei 2014, Direvisi (reviewed) : 14Mei 2014,

Disetujui (accepted) : 17 Juni 2014

\section{PENDAHULUAN}

Industri otomotif di Indonesia menunjukkan perkembangan yang cukup menggembirakan dalam satu dekade belakangan ini, ditandai dengan produksi yang meningkat dari tahun ke tahun. Namun prestasi yang diraih industri mobil yang menggembirakan ini menyimpan suatu keprihatinan karena peran potensi dalam negeri di dalam aspek desain, teknologi, dan engineering masih terbatas. Industri mobil dalam negeri hingga saat ini sepenuhnya dikuasai oleh asing atau Agen Pemegang Merek (APM). Walau industri mobil ini di satu sisi bisa dikatakan sudah cukup kuat, di sisi lain dinilai memiliki kelemahan yang sesungguhnya sangat mendesak untuk diatasi secara serius. Hal itu dikarenakan kekuatan industri mobil itu tidak didukung oleh kapasitas dalam negeri. Kapasitas yang dimanfaatkan APM praktis hanya berupa tenaga kerja untuk kegiatan perakitan mobil yaitu bagian paling hilir dari struktur industri mobil keseluruhan. Bagian inti dan strategis yaitu yang berupa desain, pengembangan, dan rekayasa justru masih dikerjakan di luar Indonesia.

Mengingat skala pasar mobil di Indonesia yang semakin besar yang dipicu oleh meningkatnya daya beli masyarakat, maka sewajarnya timbul keinginan untuk 
menghadirkan mobil yang dirancang dan diproduksi oleh industri mobil milik anak bangsa. Indonesia dengan penduduk 240 juta orang tidak pantas hanya dijadikan sebagai pasar saja dari berbagai komoditi dan produk asing. Harus ada industri mobil nasional yang tumbuh berdampingan dengan industri yang dikelola oleh APM. Untuk itu perlu disusun suatu strategi dan pendekatan dalam mengembangkan konsep industri mobil seperti dimaksud di atas dengan melibatkan berbagai pihak yang peduli pada eksistensi industri otomotif dalam negeri, fasilitas, kemampuan dan kapasitas dalam negeri. Peran konkrit dan keberpihakan pemerintah dalam hal ini tentunya mutlak sangat diperlukan pula.

\section{BAHAN DAN METODE Bahan}

Produksi mobil sepanjang tahun 2012 ternyata mencapai total 1.065 .557 unit. Produksi di tahun 2012 tersebut diperlihatkan pada Tabel 1 dengan rincian setiap bulan.

Capaian ini merupakan sebuah prestasi tersendiri, karena untuk pertama kalinya produksi mobil menembus angka satu juta. Ditinjau dari tipe mobil yang diproduksi, diketahui bahwa sebagian besar produksi adalah mobil jenis serbaguna atau multi purpose vehicle (MPV) dengan mesin 1.500cc seperti ditunjukkan pada Tabel 1. Tipe sedan diproduksi dengan mesin kapasitas $1.500 \mathrm{cc}$ hingga $3.000 \mathrm{cc}$. Kedua jenis mobil tersebut merupakan $65,5 \%$ dari total produksi tahun 2012. Mobil tipe MPV dengan mesin $1.500 \mathrm{cc}$ berbahan bakar bensin tercatat sebagai tipe mobil yang paling banyak (65\%) diluncurkan pada tahun itu, sesuai dengan minat beli dari masyarakat Indonesia. Pada Tabel 1 juga dapat dibaca bahwa kenaikan produksi mobil tiap bulan di tahun 2012, dikarenakan oleh sumbangan terbesar yang selalu berasal dari mobil MPV tipe $4 \times 2$. Dinamika kurva total produksi tahun 2012 itu dipengaruhi oleh naik turunnya kurva produksi mobil jenis MPV yang diperlihatkan pada Gambar 1.

Di balik prestasi produksi mobil pada tahun 2012 yang berjumlah sebanyak 1.065.557 unit itu, sesungguhnya terdapat suatu keprihatinan. Sebab prestasi ini baru merupakan capaian produksi oleh 19 industri mobil asing dengan sekitar 20 merek. Hingga kini belum ada mobil produksi anak bangsa yang turut meramaikan pasar di negara sendiri. Jadi selama bertahun-tahun kita baru mendapat suguhan kebanggaan semu, ditinjau dari teknologi, desain, dan kerekayasaan (engineering). Peran dan keterlibatan anak negeri ini yang berlatar belakang otomotif atau peduli dengan bidang masih jauh dari harapan. Peluang yang sebanding perlu diberikan kepada mereka sehingga mereka pun dapat mengasah kemampuan dan menguji kompetensi, serta menampilkan karya orisinil di rumah sendiri.

Tabel 1.

Produksi Mobil Tahun 2012²)

\begin{tabular}{|c|c|c|c|c|c|c|c|c|c|c|c|c|c|c|c|c|}
\hline \multirow{2}{*}{\multicolumn{3}{|c|}{ CATTEOKRY }} & \multicolumn{12}{|c|}{ WONTH } & \multirow{3}{*}{$\begin{array}{r}\text { PROD } \\
2012 \\
673\end{array}$} & \multirow{2}{*}{$\begin{array}{c}\text { SHAFE } \\
\approx\end{array}$} \\
\hline & & & Ien & leb & Mar & Apr & May & $\operatorname{sen}$ & 301 & Aug, & Sep & uct & Nov & Lec & & \\
\hline \multirow[t]{4}{*}{1.} & \multirow{3}{*}{ SEUAN IYFe } & $\operatorname{crs}=1.50 n[6 / n)$ & 10 & 79 & 47 & 5.3 & 9 & 45 & 14 & 67 & 77 & 87 & 81 & 1.53 & & 0,1 \\
\hline & & $1.500<C C=3.000 ; G) / 2.500(D)$ & 277 & 321 & 283 & 326 & 324 & 402 & 400 & 262 & 309 & 458 & 362 & 352 & 4076 & 0,4 \\
\hline & & $\propto: 3.001(G) / 2.500(D)$ & 5 & 1 & 29 & is & 10 & 24 & 13 & 9 & 5 & 2 & 3 & & 120 & 0 \\
\hline & & SUR TOTAI & 2012 & ts & 353 & 306 & 343 & $4 / 1$ & $42 z$ & 338 & 201 & $34 /$ & 446 & $50 s^{\prime}$ & $4866^{3}$ & $0,=$ \\
\hline \multirow[t]{4}{*}{2.} & \multirow{3}{*}{$4 \times 2$ lype } & $c c=1.500[6 / \pi)$ & 39502 & 49093 & 44669 & 42301 & 47790 & 489.24 & 50284 & 37145 & $489=0$ & 50125 & 49533 & 39458 & 541694 & 50,8 \\
\hline & & $1.501: C C=2.500(G / D)$ & 8492 & 8562 & 9673 & 10182 & 9722 & 10664 & 11075 & 6270 & 10091 & 11396 & 9923 & 8341 & 114982 & 10,9 \\
\hline & & $\begin{array}{l}2.5001<\propto C \leq 3.000(\mathrm{G}) \\
(x \times 1.001(G) / 2.500(0)\end{array}$ & 2011 & 2073 & 2524 & 2793 & 2517 & 2231 & 2973 & 3322 & 1041 & 3998 & $385-1$ & 3112 & 36745 & $\sqrt[3,1]{4}$ \\
\hline & \multirow{4}{*}{$4 \times 4$ lype } & SUB TOTAL & 5กติล & $=44 \geq \pi$ & รธคธล & .55776 & สnการ & ตเฉวก & $341 \mathrm{~m}$ & 46737 & $6 \div 2 \pi 5$ & 6551? & ศ.3งเก & 51441 & 62.:421 & 65,1 \\
\hline \multirow[t]{4}{*}{3.} & & $C Q \div 1.500[6 / D)$ & & & & & & & & & & & & & & 0 \\
\hline & & $1.501<C C \leq 3.000[G / / 2.500(D)$ & 3206 & 3301 & 2913 & 3300 & 3701 & 351 & 2525 & 2069 & 3101 & 3256 & 3.993 & 2335 & 37114 & 3,5 \\
\hline & & $(x \times 3.001(0) / 2.500(0)$ & 628 & $j \leq 4$ & 661 & $\therefore 45$ & 469 & 131 & 435 & $2 / 8$ & 00 & $\mathrm{ry4}$ & 142 & (3) & t/yf & 0.1 \\
\hline & \multirow[b]{3}{*}{ BU: } & SUB TOTAL & 38.34 & $725 \pi$ & 3604 & $3 \pi 54^{\prime}$ & 4170 & 41R5 & $31 n$ & 2647 & $n=4$ & 4010 & 43.35 & 1721 & 45211 & 4,7 \\
\hline \multirow[t]{3}{*}{4} & & $G V W \therefore 5 \operatorname{Ton}(G / D)$ & 214 & 284 & 186 & 289 & 283 & 784 & 359 & 147 & 165 & 199 & 103 & 48 & 3061 & 0,3 \\
\hline & & $\begin{array}{l}\text { GVW } 10-2.1 \text { Ton }[G / D] \\
\text { lovW }>24 \text { or }(G / U)\end{array}$ & 133 & 195 & 151 & 211 & 251 & 250 & 199 & 117 & 138 & 215 & 107 & 221 & 2238 & 0,2 \\
\hline & \multirow{6}{*}{ Filek upiliru=k } & SUB TOTAL & 347 & 477 & 3.37 & $50 \mathrm{n}$ & 5.74 & 1040 & $55 \pi$ & 224 & 307 & 414 & 270 & 257 & $5 \% 72$ & 0,5 \\
\hline \multirow[t]{5}{*}{5.} & & $G V / N \approx 5 \operatorname{Ton}(G / D)$ & 11096 & 14219 & 12647 & 12381 & 15384 & 14729 & 15285 & 10554 & 15533 & 17334 & 18014 & 11571 & 169747 & 15,9 \\
\hline & & GWW 5-10 Ton $[G / D]$ & 7733 & 9827 & 8515 & 8766 & 11213 & 8919 & 9875 & 8381 & 8803 & 9577 & 10231 & 8299 & 113200 & 10,8 \\
\hline & & $\mathrm{g} \mathrm{VW} \quad 10-24 \operatorname{lon}[(\mathrm{g} / \mathrm{L})]$ & 1200 & 845 & 941 & sys & $81 ;$ & 2432 & 1132 & 244 & 1124 & $12 / 2$ & 1206 & $10 ; y$ & $120 \%$ & 1.4 \\
\hline & & $\left(n w^{\prime}, 74 \tan (c / n)\right.$ & 1ววส & 3475 & 2206 & $315 \%$ & 1797 & 1724 & $1 \mathrm{~m}$ & 1318 & $14 \pi 5$ & 1625 & 1456 & $1 \mathrm{mo}$ & 211.35 & $=$ \\
\hline & & SUB TOTAL & 21925 & 27799 & 24341 & 243098 & 32341 & 26874 & 28973 & 21097 & j694.5 & $2980 \Omega$ & $3 n 9 n 7$ & 22019 & 316757 & $x, 7$ \\
\hline \multirow[t]{3}{*}{6.} & & GVW $<5$ Tun $(G / D)$ Fural $C O$ & & & & & & & & & & & & & & \\
\hline &  & SubTotel & & & & & & & & & & & & & & \\
\hline & & $\begin{array}{l}\text { Fiuciuclieil Tulal } \\
\text { dection cum ictal }\end{array}$ & $\begin{array}{l}77036 \\
1 / 036\end{array}$ & $\begin{array}{r}86169 \\
103503\end{array}$ & $\begin{array}{r}85507 \\
249012\end{array}$ & $\begin{array}{r}811126 \\
3314386\end{array}$ & $\begin{array}{r}97367 \\
430 \text { Sus }\end{array}$ & $\begin{array}{r}91399 \\
\text { 3252044 }\end{array}$ & $\begin{array}{r}97330 \\
\text { G22534 }\end{array}$ & $\begin{array}{r}71113 \\
69364 /\end{array}$ & $\begin{array}{l}9 M 188 \\
\text { PEs145 }\end{array}$ & $\begin{array}{l}100298 \\
888433\end{array}$ & $\begin{array}{r}99168 \\
98 / 001\end{array}$ & $\begin{array}{r}77955 \\
10 u b b s i s\end{array}$ & $10 b_{3}$ & 100 \\
\hline
\end{tabular}


Pada Gambar 2 memperlihatkan kurva tentang kecenderungan permintaan pasar mobil di Indonesia. Terjadi naik turunnya permintaan akan mobil yang disebabkan oleh berbagai krisis ekonomi dan politik, pengaruh kenaikan harga bahan bakar. Mulai pada tahun 2009 kurva permintaan mobil terus meningkat tajam. Untuk memenuhi permintaan tersebut, pada tahun 2012 produksi yang semula diperkirakan masih berada di bawah satu juta unit, kenyataannya sekarang sudah terlampaui yaitu mencapai 1,065 juta unit mobil.

Dengan pertumbuhan ekonomi yang cenderung terus membaik, maka pasar mobil di dalam negeri diperkirakan akan terus meningkat pula. Disamping dipenuhi oleh produksi dalam negeri, permintaan mobil juga ditutup dengan mobil-mobil impor yang kebanyakan masuk dari produsen mobil negara Asean terutama Thailand. Mobil premium kebanyakan didatangkan dari Eropa. Mengingat permintaan mobil yang kian membesar, negara perlu melakukan reorientasi terhadap industri otomotif khususnya mobil sehingga Indonesia berubah dari hanya sebagai pemilik pasar mobil yang besar, tetapi juga menjadi sebuah negara produsen mobil yang bukan lagi termasuk papan bawah, sedikitnya di kawasan Asean.

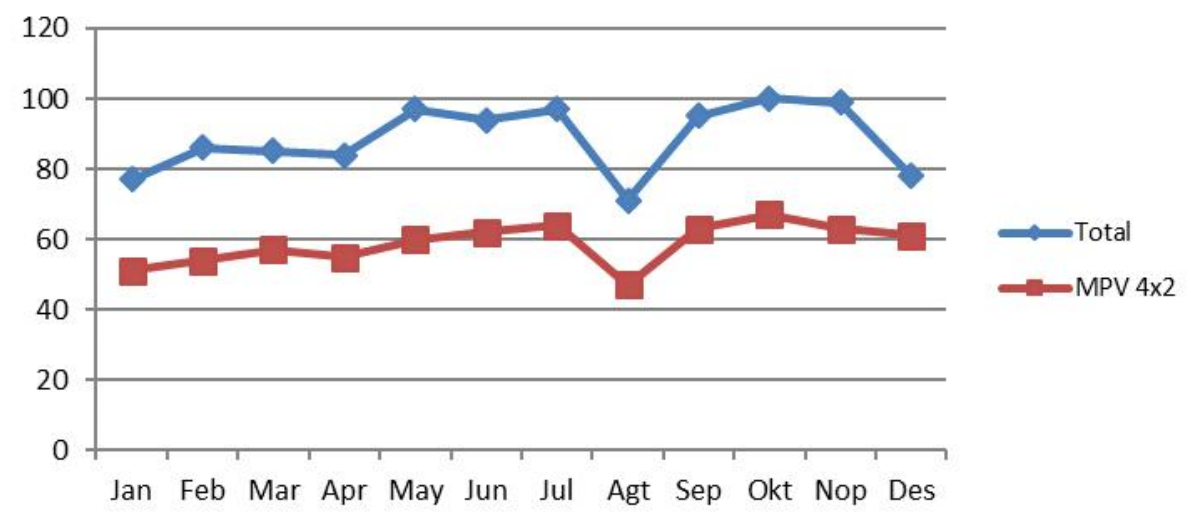

Gambar 1.

Perkembangan Produksi Mobil MPV 4x2 Tahun 2012

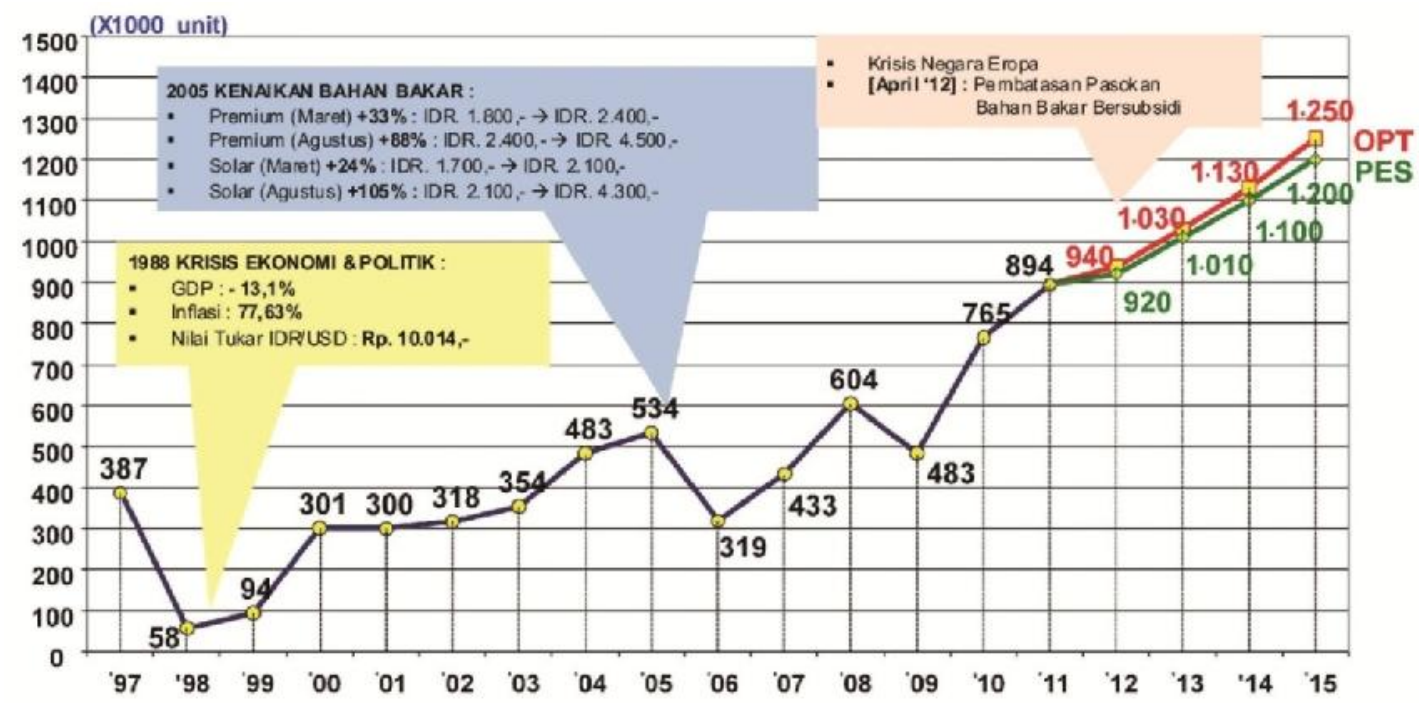

Catatan:

Asumsi pertumbuhan pasar domestik pada $2012 \mathrm{~s} / \mathrm{d} 2013,2013 \mathrm{~s} / \mathrm{d} 2014,2014 \mathrm{~s} / \mathrm{d} 2015=10 \%$

Gambar 2.

Perkiraan Pasar Mobil di Indonesia ${ }^{3)}$ 
Indonesia dengan penduduk sekitar 240 juta orang sewajarnya merupakan pasar yang sangat potensial bagi berbagai jenis produk industri manufaktur termasuk produk mobil. Masih jauh memadainya sebaran dan kualitas pelayanan transportasi umum terutama di kota-kota besar seperti Jakarta, Surabaya, Medan, Palembang telah mendorong masyarakat untuk menggunakan kendaraan pribadi berupa mobil dan terakhir ini sepeda motor yang semakin banyak memadati jalan. Di samping itu kini mobil juga telah menjadi semacam status simbol sosial bagi sekelompok komunitas di perkotaan.

Tabel 2 menampilkan keadaan pasar dalam negeri di tahun 2012 dimana telah terjual sebanyak 1.118 .230 mobil. Dari jumlah keseluruhan penjualan mobil di tahun 2012 itu didominasi oleh penjualan mobilmobil tipe MPV 4x2 sebanyak 739.168 unit, sedangkan tipe sedan sebanyak 34.221 unit.

Produksi tahun 2012 yang mencapai angka 1,065 juta dapat dikatakan baru mengisi $95 \%$ dari kebutuhan pasar tahun 2012 tersebut. Karena itu impor masih diperlukan, jumlahnya pun cenderung bertambah dari tahun ke tahun. Pada Tabel 3 ditunjukkan bahwa impor mobil dalam keadaan jadi atau completely built up (CBU) pada tahun 2012 berjumlah 125.873 unit atau $11 \%$ dari penjualan di tahun 2012. Adapun ekspor mobil CBU di tahun yang sama berjumlah 173.368 unit atau sekitar $16 \%$ dari produksi tahun 2012. Ekspor mobil ada juga yang dilakukan dalam bentuk terurai completely knocked down (CKD) dan dalam bentuk komponen, namun jumlahnya relatif masih sedikit.

Posisi perkembangan produksi mobil Indonesia dibandingkan dengan beberapa negara Asean untuk kwartal pertama tahun 2012 diperlihatkan di Gambar 3. Thailand menduduki peringkat kesatu dengan jumlah produksi 499.560 unit, diikuti oleh Indonesia dan Malaysia dengan produksi masingmasing 247.836 unit dan 141.959 unit. Thailand merupakan satu negara penghasil mobil terbesar di Asean yang menjadi pesaing bagi Indonesia. Malaysia yang sudah melangkah maju dengan merek mobil sendiri belum menjadi pesaing serius bagi Indonesia dari segi volume penjualan. Namun tetap perlu diwaspadai karena semua negara yang sudah mulai masuk dalam industri atau bisnis mobil pasti akan berupaya keras mengembangkan usaha ke tingkat yang lebih tinggi.

Tabel 2.

Pasar Mobil Domestik Tahun 2012

\begin{tabular}{|c|c|c|c|c|c|c|c|c|c|c|c|c|c|c|c|c|}
\hline \multirow{2}{*}{\multicolumn{3}{|c|}{ CATEGOR }} & \multicolumn{12}{|c|}{ MUNIH } & \multirow{2}{*}{$\begin{array}{l}\text { Prou } \\
\text { Pols }\end{array}$} & \multirow{2}{*}{$\begin{array}{l}\text { SHAKE } \\
\%\end{array}$} \\
\hline & & & I.an & For & R.A.nr & Ans & M-y & tur & IIIII & sile & $\operatorname{sep}$ & net & Nov & Dor. & & \\
\hline \multirow[t]{4}{*}{1.} & \multirow{4}{*}{ SEDAN TYPC } & $\propto \simeq 1,5 D 2(\mathrm{G} / \mathrm{C})$ & 692 & 1117 & 19125 & 1272 & 1827 & 2116 & 1822 & 1324 & 2228 & 1509 & 1621 & 1160 & 18998 & 1.7 \\
\hline & & 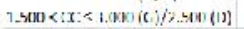 & $\therefore$ & 1144 & $\left(h^{\prime}\right]$ & בזיונור & าสา & מאוניר & תומ & $14 \mathrm{sh}$ & $1 m$ & 1044 & 1166 & 7.34) & $74 / 24$ & 1,1 \\
\hline & & $C O \cdot 3.001(\mathrm{G}) / 2.500(D)$ & 25 & 55 & 52 & 13 & 16 & 56 & 10 & 28 & 51 & 35 & 32 & 35 & 169 & 0,1 \\
\hline & & SIII TOTAI & $12 y j$ & LII. & 2240 & 2408 & 2055 & $410 \%$ & $386 ;$ & $\$ 318$ & $\$ 501$ & 2083 & 2829 & $2644^{\circ}$ & 34271 & $=1$ \\
\hline \multirow[t]{5}{*}{2.} & \multirow{5}{*}{ 4*2 Type } & $\alpha=1.500 i 6 / n)$ & 3851.5 & 45444 & 461.37 & 43993 & 49571 & 53421 & 53732 & 41979 & 54738 & 55725 & 54378 & 46749 & 583107 & $5 \% ?$ \\
\hline & & $1.501 \div \mathrm{CC} \leq 2.500(\mathrm{G} / \mathrm{D})$ & $105 \pi$ & 11003 & 12084 & 13222 & 13116 & 11108 & 13885 & 3,20 & 13025 & 15718 & 13566 & 12529 & 152282 & 13,6 \\
\hline & & $7.5001<0 r<<3.0 n n(r i)$ & 218 & $1 n 7$ & $m$ & หหล & 284 & เศก & $2 n 1$ & $1 \mathrm{~ms}$ & 210 & $74 \sqrt{3}$ & 440 & 312 & 31.70 & 0,1 \\
\hline & & $c c \cdot 3.001 ! G) / 2.500(D)$ & 22 & 33 & 29 & 126 & 87 & 60 & 65 & 77 & 16 & 52 & 38 & 13 & 619 & 0,1 \\
\hline & & SIIP TOTAI & 40450 & $s b b s<$ & $=5: 462$ & 510,0 & 63358 & $6 / 1 / \prime \prime$ & $6 / 163$ & soseses & b/jet & $112 / 3$ & 66422 & 596033 & รуบ168 & $a s, 2$ \\
\hline \multirow[t]{4}{*}{3.} & \multirow{4}{*}{$4 \times 4$ lype } & $\propto<1.500(G / D)$ & & & & & & & & & & & & & & 0 \\
\hline & & $1.501<\infty \leq 3.000(G) / 2.500$ (D) & 311 & 151 & 508 & 181 & 520 & 606 & 525 & 180 & 098 & 397 & 131 & 232 & 5653 & 0.5 \\
\hline & & $c c>7.001(G) / 7.5 n n(D)$ & $5 \pi$ & $\pi 7$ & 25 & 181 & 146 & 144 & $2 \mathrm{~m}$ & 175 & $17 \%$ & 178 & 314 & 43 & 1747 & 0.2 \\
\hline & & SUE OIAL & 359 & 591 & 603 & 662 & 666 & 750 & 735 & 592 & 850 & 575 & 618 & $2 \pi$ & 7396 & 0,7 \\
\hline \multirow[t]{4}{*}{4.} & \multirow{4}{*}{ EUS } & $G V(w) \Leftrightarrow$ on $(\mathrm{G} / \mathrm{L})$ & 1.15 & (2) & 16b & $22 \prime$ & 340 & 247 & 201 & 12: & 106 & 112 & 131 & 98 & 211 & 0.2 \\
\hline & & srov 1024 Ton $(G / D)$ & 89 & 149 & 103 & 246 & 341 & 145 & 105 & 117 & 185 & 221 & 207 & 373 & 2281 & 0,2 \\
\hline & & $\cos w \times 24 \operatorname{lon}(\mathrm{s} / \mathrm{L})$ & & & & & & & & & & & & & & 0 \\
\hline & & SUE TOTAL & 275 & $3 \pi 7$ & 288 & 473 & 6⿻1 & 392 & 307 & 247 & 791 & 333 & 3.44 & 471 & 4477 & 0.4 \\
\hline \multirow[t]{5}{*}{5.} & \multirow{5}{*}{ Pick Up/Truck } & GrW $<5$ Tun $\{G / D\}$ & 11393 & 19515 & 13024 & 12701 & 15360 & 13813 & 15355 & 10189 & 11559-1 & 17636 & $171 / 4$ & 12610 & 168351 & 15,1 \\
\hline & & GWvis $s-I D \operatorname{lon}[G / D]$ & J14s & 241 & Et: $/ 9$ & bas! & $8.0 \%$ & 530e & gos: & jN & -416 & $2 / 31$ & 1usobs & בנים & $200 / 33$ & 2,3 \\
\hline & & Swa $1024 \operatorname{Tor}(G / \mathrm{C})$ & 1048 & 782 & 936 & 906 & 833 & 1386 & 1209 & 899 & $135 \mathrm{~s}$ & 1414 & 1178 & 806 & $12 \pi 56$ & 1,1 \\
\hline & & $\operatorname{csw} \times 24 \operatorname{lon}\left(c_{s} / L\right)$ & $20 y$ & $21 w 0$ & 2141 & 2900 & $1 / 26$ & 1800 & $1+34$ & 1200 & $1 \leqslant \omega$ & 1482 & $12 / 2$ & ל ל & $20 / 06$ & 1.9 \\
\hline & & SUETOTAL & 24183 & 25974 & 24806 & 74494 & 76626 & 26397 & 27155 & 19917 & 70707 & 30313 & 3nก99 & 24623 & 311609 & 27,9 \\
\hline \multirow[t]{4}{*}{ G. } & Joule catan & GWW $<5$ Ton $(G / D)$ Foral CC & 373 & 710 & $1 / 92$ & $1 / 28$ & 1355 & 2323 & 2181 & 1704 & 2103 & 1577 & 1371 & 1611 & $193 \mathrm{GM}$ & 1.7 \\
\hline & & Sub Tulal & 373 & 715 & $14 \subseteq 2$ & 1128 & 1355 & 2323 & 2181 & 1704 & 2103 & 1577 & 1371 & 1611 & 19361 & 1,7 \\
\hline & & nfluction Tntal & 76427 & R.4486 & 87917 & 87144 & 25541 & 101746 & 102511 & 76445 & 103100 & 106754 & 103703 & 89456 & & 100 \\
\hline & Pred & untion Cum Total & 76127 & 162913 & 250830 & 337974 & 433515 & 535261 & 637772 & 711217 & 810317 & 923071 & 1026774 & 1116230 & & \\
\hline
\end{tabular}

Tabel 3.

Ekspor Dan Impor Mobil Tahun 2012²)

\begin{tabular}{|c|c|c|c|c|c|c|c|c|c|c|c|c|c|}
\hline \multirow{2}{*}{ CATEGOFY } & \multicolumn{12}{|c|}{ MONIII } & \multirow{2}{*}{$\begin{array}{l}\text { SALLS } \\
2012\end{array}$} \\
\hline & Ian & $\mathrm{F}_{t} \mathrm{t}_{\mathrm{r}}$ & Mar & Ap & MaY & har: & $|u|$ & Alu & SHF & no: & Neve & DHE: & \\
\hline \multicolumn{14}{|l|}{ EXNORIS } \\
\hline CLU (UNIT) & 14477 & 14583 & 14980 & 1575) & 13007 & 14097 & 13225 & 11652 & 17432 & 17283 & 14067 & 12806 & 173358 \\
\hline CKD (SET) & $85 \pi$ & 9872 & 8369 & 9723 & 7040 & 7870 & $s 640$ & 6635 & 8510 & 3010 & 7368 & 6864 & 100122 \\
\hline COMPONENTS (PIECES) & 3534198 & 4785330 & 3596964 & 4754883 & 4801520 & 4715340 & 5933608 & 4313003 & 4720392 & 4720392 & 3996114 & 5021564 & 55504758 \\
\hline CEU (UNIT) & 5425 & 8952 & 5503 & 7900 & 10551 & 12563 & $1130 ?$ & 9573 & 14179 & 14511 & 14254 & 7105 & 125873 \\
\hline
\end{tabular}




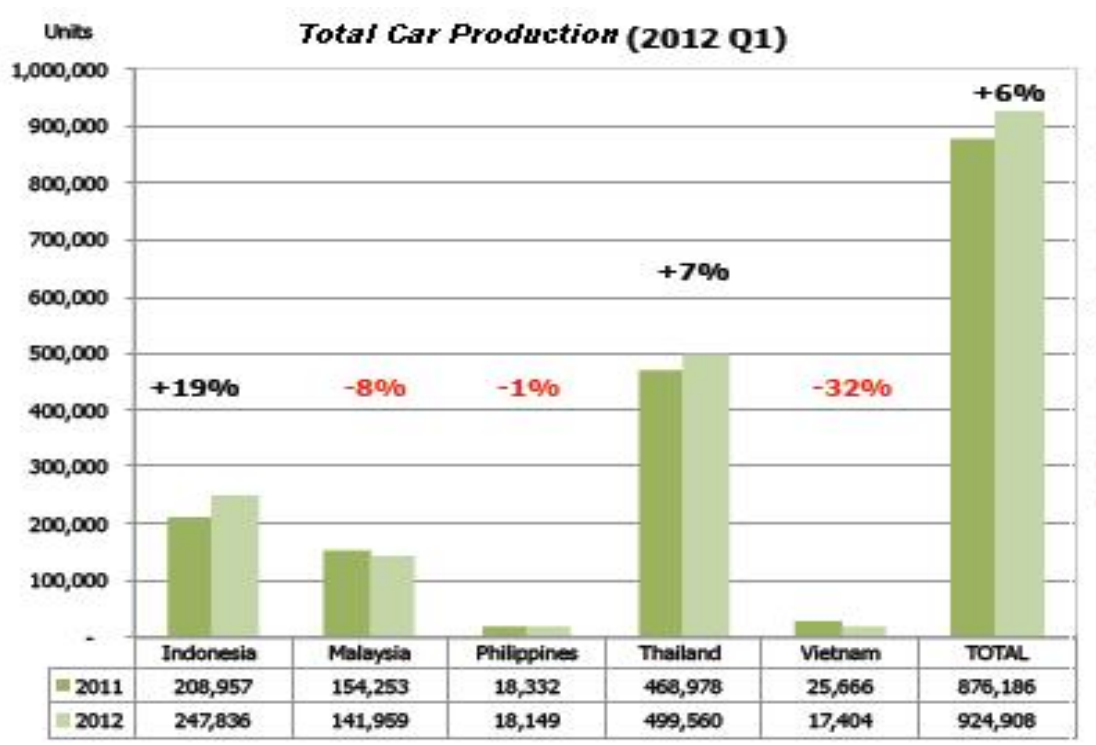

Gambar 3.

Produksi Mobil Negara Asean Pada Kwartal 1 Tahun 2012 ${ }^{1)}$

Produksi mobil Thailand jauh melebihi kebutuhannya di dalam negeri sehingga sebagian di ekspor. Tujuan ekspornya yang terbesar adalah Indonesia, sehingga sejak awal tahun 2000an dapat disaksikan mobilmobil impor antara lain merek Honda, Toyota, Mitsubishi, Chevrolet yang berasal dari negara gajah putih tersebut. Keadaan ini bukan terjadi begitu saja, tetapi sudah merupakan suatu rencana dan kebijakan pengembangan industri kendaraan bermotor yang konsisten di Thailand. Kebijakan perdagangan antar negara Asean pun mendukung langkah-langkah perdagangan yang ditempuh Thailand.

Masih tingginya impor mobil pasti menguras cukup banyak devisa. Disamping itu, adalah tidak adil bilamana impor itu berasal dari negara Asean yang memiliki penduduk lebih sedikit dari negara kita, sementara industri mobil dalam negeri Indonesia kapasitas produksinya seolah-olah dipertahankan pada tingkat yang relatif rendah. Apapun alasannya, keadaan ini harus dikoreksi. Kalau Thailand saja berhasil menarik industri mobil dunia untuk menjadikan negaranya sebagai salah satu basis produksi, maka Indonesia pun patut mendapatkan peran yang serupa.

Persoalan berikutnya yang lebih mendasar adalah ketergantungan industri mobil dalam negeri terhadap teknologi dari luar negeri. Peran sumberdaya manusia Indonesia di industri mobil dalam negeri masih banyak terbatas pada proses perakitan mobil, pemasaran dan purna jual. Keterlibatan dalam urusan teknologi dan pengembangannya pun sangat terbatas. Ini dikarenakan pusat pengembangan disain dan pengembangan mobil masih berada di negara industri induk (principal) atau di luar Indonesia.

Serupa dengan keadaan tersebut, industri komponen mobil juga kurang berkembang terutama dari aspek teknologi dan rancang bangun. Demikian pula dengan independensi industri komponen tersebut yang rendah disebabkan oleh kedekatan sebagian besar industri komponen dengan industri mobil yang membinanya dari semula.

\section{Metode}

Kajian dilakukan dengan menghimpun berbagai informasi dan data dari bermacam sumber, tulisan terdahulu dan berita aktual di lapangan. Kemudian diikuti dengan bahasan dan analisis.

\section{HASIL DAN PEMBAHASAN Paradigma baru}

Berdasarkan pada persoalan yang dihadapi sebagaimana diutarakan sebelumnya, maka mengingat tuntutan adanya bangun industri, negara perlu berbenah atau melakukan reorientasi bagi penguatan industri mobil yang lebih seimbang. Mengacu pada isi PP No. 28 Tahun 2008, dicantumkan industri alat angkut sebagai salah satu industri andalan masa depan. Gambar 4 menampilkan sosok dari bangunan industri nasional yang akan dicapai pada Tahun 2025. Bangunan industri nasional tersebut harus dibangun dengan sumber daya manusia Indonesia melalui riset 
dan rekayasa, memanfaatkan sumber daya alam secara efektif dan efisien. Oleh sebab itu, industri otomotif termasuk industri mobil sebagai bagian dari sebuah industri alat angkut tentunya harus dikembangkan dengan skenario yang serupa.

Basis industri manufaktur yaitu suatu spektrum industri yang sudah berkembang dan telah menjadi tulang punggung sektor industri. Kelompok industri ini keberadaannya masih sangat tergantung pada sumber daya alam dan sumber daya manusia tidak terampil. Ke depan perlu direstrukturisasi dan diperkuat agar mampu menjadi industri kelas dunia. Industri-industri andalan masa depan meliputi: Industri Agro (industri kelapa sawit, pengolahan hasil laut, karetpulp dan kertas), Industri alat angkut (industri otomotif, perkapalan, kedirgantaraan, dan perkeretaapian), Industri telematika (industri perangkat atau devices, infrastruktur/jaringan dan aplikasi/content).

\section{Strategi penguatan industri mobil}

Bagaimana bangun industri otomotif atau industri kendaraan bermotor yang cukup ideal bagi Indonesia? Walau berbagai argumentasi dapat dikemukakan tentang bangun industri otomotif, namun dilihat dari skala pasar domestik, kapasitas kompetensi nasional, serta aspirasi para teknorat, maka sewajarnya industri otomotif yang sekarang ada dilengkapi dengan industri yang mengusung produk rancangan, merek, dan ditangani sendiri oleh putera bangsa ini. Gambar 5 merupakan sketsa bagaimana industri mobil murah yang harus cukup unggul dalam kualitas, biaya, dan pasokan (delivery) atau QCD sehingga dapat tampil berdampingan bersama-sama dengan industri mobil dari APM yang sudah lama beroperasi di Indonesia.

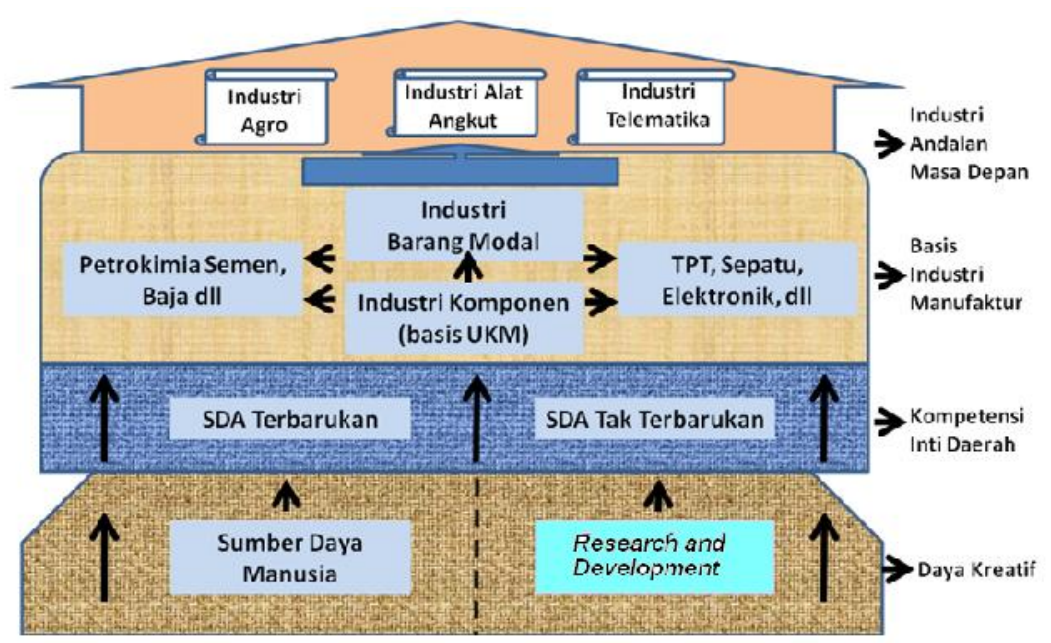

Gambar 4.

Bangunan Industri Nasional Tahun 2025

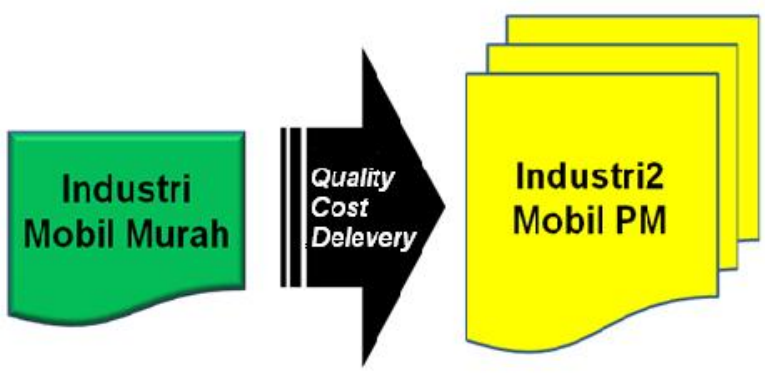

Gambar 5.

Pengembangan Industri Mobil Nasional ${ }^{4)}$ 


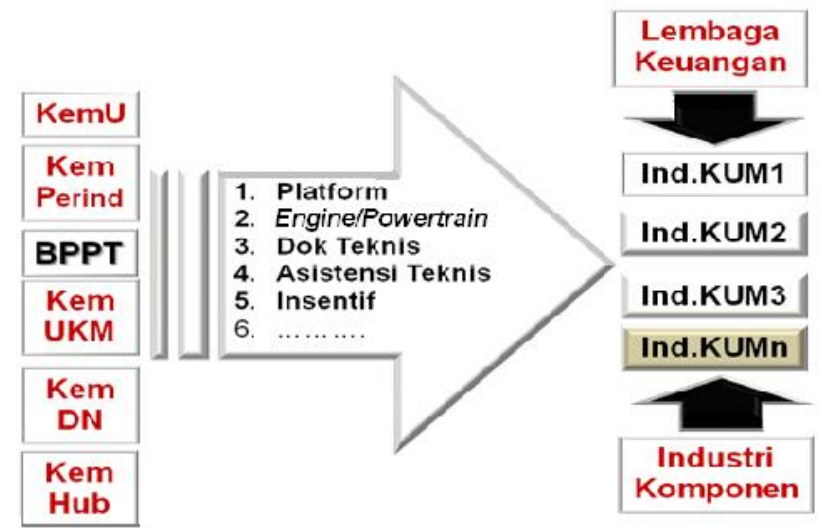

Gambar 6.

Tipikal Industri Mobil Murah ${ }^{4)}$

\begin{abstract}
Selanjutnya Gambar 6 merupakan sebuah ilustrasi dari tipikal skenario pengembangan industri mobil murah. Mulai dari embrionya hingga matang, industri ini membutuhkan sebuah suasana kondusif yang diciptakan oleh sejumlah instansi terkait. Dalam skenario ini industri mobil murah akan dibidani oleh BPPT yang didukung oleh Kementerian Perindustrian, serta antara lain Kementerian Perhubungan, Kementerian Dalam Negeri. BPPT dalam hal ini akan menyiapkan komponen utama terutama platform mobil, mesin, yang memenuhi standar keselamatan dan kelayakan jalan, berikut dokumentasi teknis, asistensi teknis. Industri mobil/kendaraan umum murah (KUM) terutama di masa-masa awalnya pasti membutuh pula serangkaian insentif dari lembaga keuangan dan perbankan. Industri komponen otomotif pun sangat diperlukan bahkan berperan strategis dalam membangun produk mobil yang didambakan tersebut secara utuh dan berkelanjutan.
\end{abstract}

\section{Kebijakan yang mendukung}

Pemerintah telah memposisikan sektor otomotif sebagai salah satu dari lima industri prioritas negara yang menjadi fokus. Dewasa ini Indonesia menduduki peringkat pasar mobil terbesar di Asean. Namun sebagai produsen mobil, Indonesia berada di bawah Thailand. Peraturan Presiden Nomor 28/2008 menyatakan bahwa sasaran produksi mobil tahun 2015 sebesar 1,6 juta unit dari mobil tipe serbaguna atau multi purpose vehicle (MPV), truk ringan dan mobil hijau dan hemat energi. Disamping itu ditetapkan pula sasaran ekspor sebesar 386.000 unit.

Karena itu di awal Tahun 2011, pemerintah melalui Kementerian Perindustrian mulai memperkenalkan konsep mobil low cost green car atau LCGC dan mobil murah. Mobil LCGC diperkirakan mempunyai potensi pasar dari kalangan menengah sebesar 300.000 unit per tahun. Sedangkan mobil murah diharapkan mampu mengisi ceruk pasar untuk banyak daerah. Mobil LCGC yang digariskan memiliki mesin dengan isi silinder $1.000 \mathrm{cc}-1.200 \mathrm{cc}$ akan ditawarkan pengembangannya kepada agen pemegang merek atau APM sedangkan mobil murah yang ditandai dengan bermesin di bawah $1.000 \mathrm{cc}$ diperuntukkan pengembangannya khusus kepada potensipotensi dalam negeri di luar lingkungan APM.

Namun peraturan resmi tentang konfigurasi dan deskripsi LCGC hingga hari ini belum terbit sehingga dirasakan sebagai suatu wacana saja. Di lain pihak, proses pengembangan mobil murah pun mengalami turbulensi yang mengakibatkan lambatnya capaian. PT Inka yang semula aktif dalam mobil murah, sekarang membatasi diri. Padahal mobil angkutan umum murah ini sudah dideklarasikan oleh Presiden SBY pada bulan Februari 2011 bertempat di Istana Bogor, yaitu sebagai bagian dari Enam Program Pengentasan Kemiskinan dalam rangka Millenium Development Goal atau MDG. Isu yang mengatakan bahwa ketentuan resmi mengenai LCGC akan dikeluarkan dalam atau bagian dari Peraturan Presiden tentang Low Carbon Emission atau LCE yang juga masih dinantikan.

Untuk program mobil murah, sebetulnya harus dipacu dan dikoordinasikan secara lebih intensif. Momentum yang ada harus dipakai secara efektif. Pengalaman pahit di masa lalu dimana berbagai upaya mewujudkan mobil Indonesia sendiri seperti mobil Maleo, Timor, Perkasa, Tawon, Kancil yang mengalami kegagalan, tidak boleh terulang. 
Mobil murah sekarang ini dikoordinasikan oleh Menko Perekonomian dan ditugaskan kepada Kementerian Perindustrian, yang selanjutnya ditangani oleh BPPT berdasarkan Memo Kesepakatan (MOU) antara Kepala BPPT dengan Direktur Jenderal Industri Unggulan Berbasis Teknologi Tinggi di bulan April 2012. Sebagai realisasi kerjasama tersebut, BPPT mendapat sejumlah perangkat lunak dan perangkat keras untuk perancangan dan pembuatan prototipe yang diperlukan mobil murah. BPPT sendiri pada tahun anggaran 2013 mengalokasikan dana untuk mendukung desain penggerak (power train) dan pembuatan prototipe platform.

Bilamana BPPT nanti berhasil meluncurkan platform mobil murah yang teruji, memenuhi karakteristik kinerja yang diingini, maka supaya industri mobil murah mampu tumbuh dan berkembang masih dibutuhkan serangkaian kebijakan pemerintah yang bisa mengantarkan industri dalam negeri untuk memproduksi mobil murah tersebut, dengan kakakteristik yaitu murah harga awalnya, murah operasinya, cocok dan handal penggunaannya di pedesaan. Kebijakan yang dimaksud antara lain adalah kebijakan penelitian dan pengembangan, kebijakan perhubungan, kebijakan industri, kebijakan keuangan (fiskal, pajak), kebijakan perdagangan, kebijakan otonomi daerah.

\section{SIMPULAN}

Industri otomotif, khususnya industri mobil nasional harus berbenah. Dari hanya sekedar sebuah pasar mobil yang besar, negara harus merubah keadaan, berbuat dengan membangun industri mobil yang seimbang dengan paling tidak antarnegara Asean. Industri mobil yang mulai dikembangkan saat ini hanya mengambil ceruk pasar yang belum dan tidak disentuh oleh APM. Dari perkiraan pasar ke depan katakanlah 1,5 juta unit/tahun, maka persentase yang akan diraup industri mobil murah hanya sekitar $5 \%$ saja atau 75.000 unit. Ini sebuah angka yang pantas bagi negara dengan potensi pasar mobil yang terus tumbuh. Karena itu tidak ada alasan dari pihak manapun untuk meragukan kehendak memiliki industri mobil karya sendiri. Justru sekarang dituntut dukungan dan keberpihakan bagi kelangsungan langkah yang telah di ambil.
Karena industri mobil murah ini dipelopori oleh entitas pemerintah, dibutuhkan pula dukungan konkrit yang konsisten dari jajaran pemerintah terkait. Hal ini sungguh diperlukan untuk mempertahankan spirit para pelaku dalam mengejar sasaran yang direncanakan sehingga momentum penetrasi pasar pun tidak tersia-siakan. Bagi masyarakat luas di perdesaan didorong pula apresiasinya terhadap produk dalam negeri seperti mobil murah ini yaitu dengan memanfaatnya. Dengan demikian akan terjadi komitmen bersama yang timbal balik antara industri dan pasar dalam negeri yang masing-masing bertanggungjawab di bidangnya.

Memang membangun industri seperti industri mobil ini tidak semudah membalik telapak tangan. Negara seperti Korea Selatan, bahkan Jepang sekalipun dahulu melakukannya secara bertahap, tetapi senantiasa didukung dengan tekad, komitmen, dan konsistensi dari para pelakunya, termasuk masyarakat.

\section{UCAPAN TERIMA KASIH}

Pada kesempatan ini penulis menghaturkan terima kasih dan apresiasi kepada semua pihak yang telah berkenan membantu dalam berbagai hal, untuk kelancaran pelaksanaan kajian ini dari semula hingga akhir.

\section{DAFTAR PUSTAKA}

1. Limpaitoon,Aa.,path of Thai Autoparts Manufacturers Toward Asean Economic Community, 21/6/2012

2. .......... Data produksi dan pasar mobil dari Gaikindo, tahun 2012.

3. .......... Direction on Industrial Policy on LCE Car Production, Dirjen. IUBTT, 2012

4. ......... , Materi program kendaraan umum murah, PTIST, 2013

5. ........., Peraturan Presiden No. 28 tahun 2008 tentang Kebijakan Industri nasional 